\title{
Providing Human Tissue for Research: 1996-2006
}

\author{
Christopher Womack Neil M. Gray \\ AstraZeneca, Cancer and Infection Research Area, Mereside, Alderley Park, Macclesfield, UK
}

\author{
Key Words \\ Human tissue $\cdot$ Research • Repository
}

\begin{abstract}
This article details the authors' experience establishing infrastructure for tissue collection, storage and distribution for biomedical research, firstly within a public healthcare service and latterly in the pharmaceutical industry. Access to human tissue in the context of public-private collaboration in research and development is essential to the provision of high-quality medicines and healthcare and is now supported by a new legal framework in England and Wales. Through collaborations there are opportunities for mutual benefit for patients and professionals alike. Attention to the wishes of tissue donors through informed consent at the outset ensured confidence and continued activity when so-called 'organ retention scandals' emerged midway through this period. The overwhelming majority of potential donors support the use of their tissues in biomedical research irrespective of where the research is carried out.
\end{abstract}

Copyright $\odot 2007$ S. Karger AG, Basel

\section{Introduction}

Following careful consideration of legal, ethical and safety issues [1-3], the authors established a research human tissue bank within the pathology department at Peterborough Hospitals (PH) in the English National Health
Service (NHS) in 1996 to meet the demand for human tissue we knew existed in the commercial pharmaceutical and biotechnology (P\&B) industry. We already had key links with local commercial contract research organisations. The business plan, to provide secondary cellular pathology services through a trading account in the hospital, Peterborough Cellular Pathology Services (PCPS) to the $\mathrm{P} \& \mathrm{~B}$ industry to generate an income stream for the hospital was fulfilled rapidly with a steady increase in client base from 3 in year one, to over 100 at its peak. Ten years later and still using the same principles, both authors moved to the pharmaceutical industry to establish a supply of human tissue and cellular pathology services for cancer research and drug development.

\section{Legal and Ethical Issues}

In the year or so leading to the tissue bank launch in June 1996, we could find no relevant law in the UK and our approach to the legal and ethical issues of supplying human tissue for research predominantly in the commercial sector was led by the Nuffield Council Report published in April 2005 [4]. Through our prospective individual consent processes, we ensured that donors/families were aware we were intending to supply their donated tissue for research at $\mathrm{P} \& \mathrm{~B}$ companies.

The tissue acquisition process including patient and donor/family consent remained largely unchanged throughout and together with donation of dead bodies

\section{KARGER \\ Fax +4161306 1234 \\ E-Mail karger@karger.ch}

www.karger.com (c) $2007 \mathrm{~S}$. Karger $\mathrm{AG}$, Basel

$1015-2008 / 07 / 0744-0212 \$ 23.50 / 0$

Accessible online at:

www.karger.com/pat
Dr. Christopher Womack

AstraZeneca, Cancer and Infection Research Area, Mereside, Alderley Park Macclesfield, Cheshire SK10 4TF (UK)

Tel. +441625233 688, Fax +441625 510097

E-Mail chris.womack@astrazeneca.com 
Table 1. Total patient interviews conducted by pathology liaison nurses for 6 consecutive full years at $\mathrm{PH}$ and cadaveric tissue retrievals done at $\mathrm{PH}$

\begin{tabular}{lrrll}
\hline Year & Interviews & 'No tissue' & Refusals & $\begin{array}{l}\text { Cadaveric } \\
\text { retrievals }\end{array}$ \\
\hline 1999 & 470 & 38 & 4 & 15 \\
2000 & 1,031 & 271 & 4 & 16 \\
2001 & 1,000 & 249 & 15 & 20 \\
2002 & 1,031 & 250 & 15 & 16 \\
2003 & 927 & 289 & 17 & 16 \\
2004 & 1,468 & 335 & 15 & 7 \\
\hline Total & 5,927 & 1,432 & 70 & 90 \\
& & & 5 for commercial \\
& & & research & \\
\hline
\end{tabular}

Note: (i) All patients were interviewed prior to surgery. (ii) 'Organ scandals' January 2001. (iii) One full-time equivalent nurse from 1999 and a further full-time nurse employed in 2004 to allow for additional duties including autopsy consent. (iv) Reasons for 'no tissue' collected were: no tissue (operation cancelled or inoperable), all tissue required for diagnosis or late finish to operation.

for research, was unaffected by the so-called 'organ retention scandals' [5, 6] in England (table 1). Although initially surprised at the high donation rate for surplus surgical tissue at $\mathrm{PH}$, a recent review shows that our experience is similar to others [7]. Our observation, that very few donors specifically object to research in the commercial sector [8] (table 1), to our knowledge, remains unique. Families are also willing to allow donation of tissue for research from the deceased $[9,10]$.

Attempts to engage the Department of Health failed until the 'organ retention scandals' came to general media attention in January 2001. We were then able to contribute to open consultation in a positive manner and now Government has provided legislation (Human Tissue Act 2004) [11] and through this, a framework for best practice delivered by the Human Tissue Authority [12]. Consent that is proportionate to risk underpins the $\mathrm{Hu}$ man Tissue Act and from 1st September 2006, establishments storing human tissue for research purposes require a licence. The licensing process aims to drive up standards. Complementary changes to the NHS research ethics structure including voluntary registration for research tissue banks [13] should further strengthen public confidence. We believe restoration of professional confidence has some way to go.

Providing Human Tissue for Research
We maintain our persistent and underlying principle that there is no monetary value attached to human tissue samples, which is in line with current European recommendation [14]; this is also generally accepted internationally. When using human tissue samples, ethical considerations must affect business decisions irrespective of whether funded in the public or private sector [3].

\section{Public Sector Experience}

The PH tissue bank comprised two elements: not-forprofit tissue acquisition and profitable biomaterials processing (provided by PCPS).

The political climate in the late 1980s and early $1990 \mathrm{~s}$ together with the NHS Act (1990) [15] and an emphasis at the time, on competition between NHS hospitals, focused our attention on the future of local provision of cellular pathology services. We were within a 40 -mile radius of three major teaching, university hospitals and at the same time commercial pathology and pharmaceutical companies were beginning to enter the NHS pathology arena. One commercial company had successfully negotiated the pathology services of a large primary general medical practice away from $\mathrm{PH}$ and we felt threatened as a local service provider. An independent, external management review of local pathology services in 1995 had confirmed limited scope for efficiency savings. The plan was to generate income by devising a method to collect human tissue that would otherwise be discarded and pass it on to the $\mathrm{P} \& \mathrm{~B}$ industry recognising the impending significant demand for human tissue in biomedical research. The primary purpose of the tissue bank was to enhance the provision of public funded NHS cellular pathology services through collaboration with the commercial P\&B sector. Systematic collection of tissue for research is not part of the core activity of the NHS and collaboration with the $\mathrm{P} \& \mathrm{~B}$ industry was seen to be the only practical way forward in busy general hospitals.

Attendance at a commercial conference in London in November 1995 provided a mail shot opportunity. There was no further advertising. The general manager responsible for $\mathrm{PH}$ pathology agreed to underwrite the initial modest costs and all the work including preparation for the local research ethics committee (LREC), was done in spare time. Following LREC approval, the tissue bank was established in June 1996, with three commercial clients and two borrowed shelves in a freezer in a neighbouring department. Initial experiences are published elsewhere [1]. Within 2 years the client base had grown to 
10 and turnover for mainly daytime tissue collection and out-of-hours processing meant that the workload was no longer manageable. A relationship built with one biotechnology company coincidentally founded at the same time as the tissue bank and initially contacted in the mail shot, identified four stepwise 'levels' of collaboration with the ultimate potential for the building of a dedicated tissue processing facility on the $\mathrm{PH}$ site. 'Level one' was to increase tissue acquisition by the appointment of two nurses to obtain patient consent and to integrate commercial cellular pathology services into the NHS laboratory in the normal working day with funding for additional staff. Costing was negotiated principally by the pathology services manager and ratified by $\mathrm{PH}$ finance department. We had also gained three additional commercial collaborations for cellular pathology-based services. In the meantime the cadaveric programme was established with further approval from the LREC in 1996 [9].

'Level one' led to a marked rise in tissue acquisition and biomaterials processing. Acquisition had now become targeted towards specific client requirements rather than collection and storage for potential future use. In 'level two' the biotechnology company provided funding to underwrite the cost of a portable cabin remote laboratory on the Peterborough District Hospital site. The company provided the equipment including safety cabinets for fresh tissue handling. The laboratory housed company and NHS employed staff. A similar portable cabin office provided accommodation for tissue bank manager, nurses and support staff. After a year's delay due to various problems including inadequate power supply, the 'level two' facilities were opened in November 2000. A fully integrated NHS/commercial tissue-handling laboratory in modified existing facilities would have constituted 'level three'. 'Level four' was to be a new public/private building.

By mid 2001 we identified the following problems:

- Working at capacity - health and safety considerations limited the number of laboratory technicians that could be accommodated and biomaterials processing capacity was reached rapidly.

- Surgical case mix and volume - in a district/general hospital such as Peterborough, limits the range of tissue available exposing supply and demand mismatch.

- Increasing client demand for tissue volume and biomaterial complexity identified a need to expand to incorporate new techniques that were not available through NHS funding.

- Piecemeal development - underwritten by P\&B collaboration had been usual and successful so far, but public funding for activity that is not part of core services is virtually impossible in the cash-limited NHS. The long-term vision did not seem compatible with public funding. Use of human tissue was by now the subject of adverse media attention the outcome of which was difficult to judge at the time.

- Lack of investment opportunity - new biomaterials' developments on site were under the control of one commercial company but in a collaboration, C.W. and N.G. with another PH director personally funded the establishment of a separate limited company in order to develop paraffin and frozen tissue arrays. Tissue arrays were just one way to maximise the increasingly scarce tissue resource.

- Peterborough - the city is unusual for its size in having no degree-awarding higher education facility, which significantly limits opportunity for academic backing. In a different geographical location the tissue bank would have provided opportunity for academic research.

- Competition - the Peterborough tissue bank was becoming well known and other banks based on an identical or similar model were being developed in centres where some of the problems above would be more easily addressed. Many of these new banks were intending to follow the Peterborough model.

As a solution we had consistently suggested a coordinated national network of research tissue banks $[1,2]$ and this formed the basis of a formal business plan we wrote with a view to securing significant, long-term development. The plan (fig. 1) was based on a biomaterials factories fed by a network of tissue acquisition centres based on NHS hospitals linked by an information technology platform. Peterborough would play a key role. The plan was presented to the PH Board where it was considered, quite rightly, inappropriate to commit capped public funds to the proposed venture. The $\mathrm{PH}$ Board gave us permission as employees, to seek a commercial partner. We had neither sufficient personal funds to invest nor the experience of raising capital from the finance sector. We considered that it was probably unethical and not appropriate that the partner should be an end user of tissue as the plan sought to provide comprehensive biomaterials resource for the $\mathrm{P} \& \mathrm{~B}$ industry generally.

Following an evaluation we tabulated our requirements against potential partner company profiles (table 2). The table includes 4 UK and 7 US companies. Following $\mathrm{PH}$ Board approval, negotiations were delegated to PH senior managers and PCPS was sold in December 2002. 


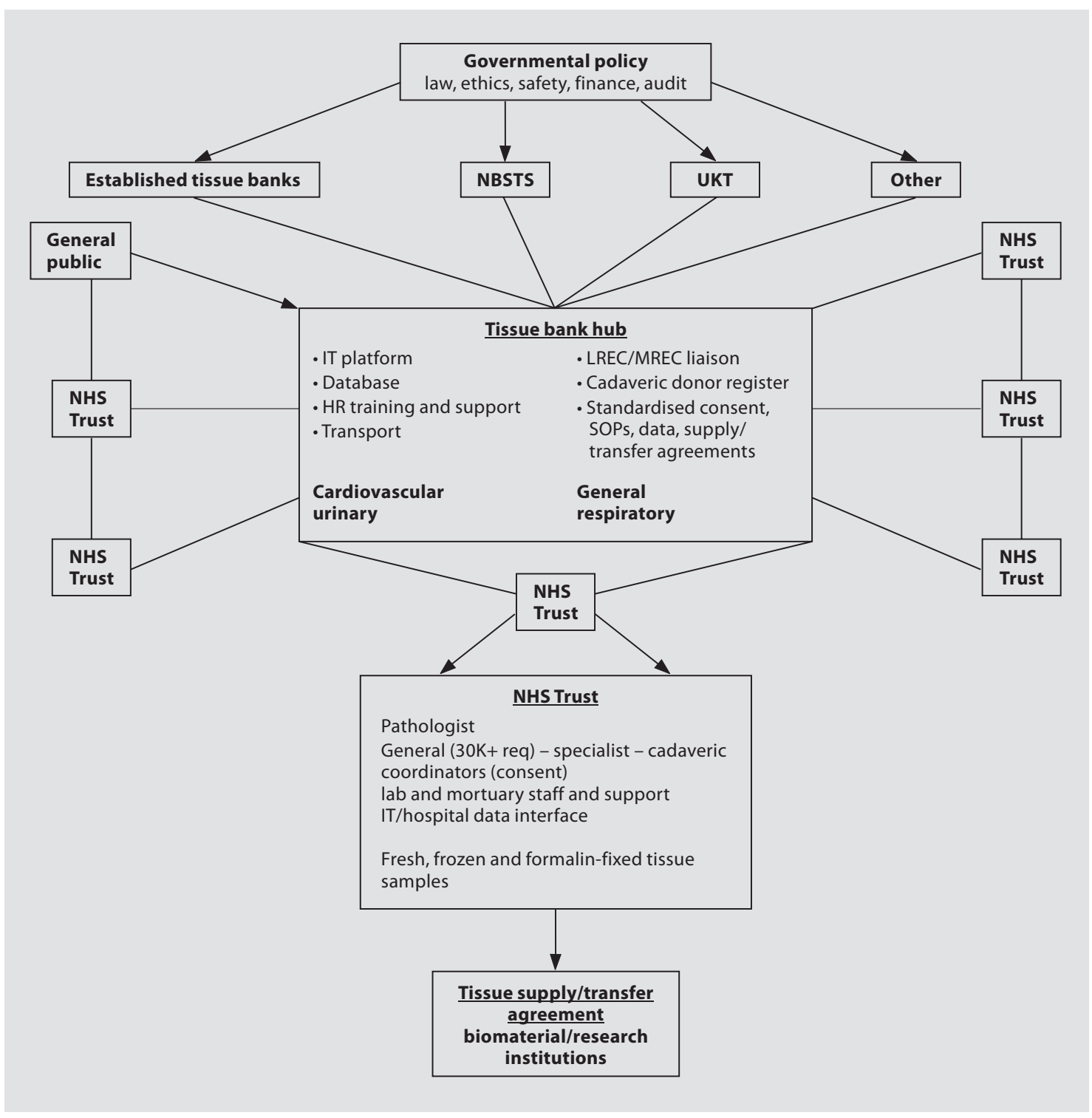

Fig. 1. Extracted from a business plan submitted by the authors to the PH Board in 2000, outlining a scheme for a national network of research tissue banks linked by a central hub. HR = Human resources; NBSTS = national blood service tissue services; SOP = standard operating procedures; UKT = UK transplant.

Following the takeover, responsibility for tissue acquisition remained with PH in the NHS with the following features:

- Protects interest of NHS patients

- Cost recovery - no monetary value attached to tissue itself

- Probity of a public service

- Clinical, corporate and research governance in place to national requirements
- Recognises that acquisition ends and 'process' begins when surplus fresh tissue is handed to the Company (and leaves the NHS)

- Extended role of nurse - 'pathology liaison/specialist' nurses providing face-to-face consent interviews with donors and families [16]

- Extended role of Biomedical Scientist - opportunity for development with a shortage of trained histopathologists. 
Table 2. Evaluation of potential $P \& B$ partners for $\mathrm{PH}$

\begin{tabular}{|c|c|c|c|c|c|c|c|c|c|c|c|}
\hline \multirow[t]{2}{*}{ PCPS requirements } & \multicolumn{11}{|c|}{ Potential P\&B partner profiles } \\
\hline & 1 & 2 & 3 & 4 & 5 & 6 & 7 & 8 & 9 & 10 & 11 \\
\hline Digital image analysis & & $x$ & & & & & & & & & $x$ \\
\hline Proteomics & & $\times$ & & $x$ & & $\times$ & $x$ & $x$ & $\times$ & & $x$ \\
\hline Telepathology & & & & & & & & & & & $x$ \\
\hline Contract services & & & & $\times$ & & $\times$ & & & & & $x$ \\
\hline Biomaterials processing & $x$ & & $\times$ & $x$ & $x$ & $\times$ & $x$ & $x$ & $\times$ & $\times$ & \\
\hline Information technology & & & $\times$ & & & $x$ & $\times$ & & & & $x$ \\
\hline Histopathologists & $x$ & & & & & & & & & & $x$ \\
\hline
\end{tabular}

Note: (i) Potential partner 1 was PCPS; (ii) partner 11 was chosen.
The deal guaranteed income to the hospital over an initial 2-year period as well as a profit share but this was not sustainable by either party in the long term. In common with most other NHS hospitals, $\mathrm{PH}$ had precarious finances but as a general hospital, did not support inhouse human tissue-based research, and in late 2005 the $\mathrm{PH}$ Board decided to close the facility with effect from the end of March 2006.

\section{Pharmaceutical Experience}

As we predicted, the need for human tissue in drug discovery-related research has continued to grow as a result of the Human Genome and Proteome Projects, increased knowledge of molecular mechanisms of disease and introduction of high throughput technologies. Examples of uses of human tissue in P\&B are: therapeutic monoclonal antibody testing, receptor binding assays, functional pharmacological assays, gene expression/profiling, cytotoxicity studies, metabolism/pharmacokinetics studies, high throughput scanning to analyse and validate target profiles, generating primary cell cultures, tissue microarrays and normal immunohistology controls.

Now, working for a major pharmaceutical company brings us new challenges that are focussed on cancer. During 2006 we engaged our erstwhile colleagues in the NHS and universities as well as commercial suppliers in order to secure the biomaterials required for our internal research activities including our own new immunohistochemistry facility. We have established a trans-Atlantic cancer research area tissue bank that is now being stocked following consultation with our disease and biological effect area teams in oncology. We have found that commer- cial suppliers are prepared to work to tissue quality standards that are far more exacting than we were asked for during our previous existence (e.g. to obtain surgical tissue with ischaemia times down to $15-20 \mathrm{~min}$ ), though this is expensive. Universities and NHS hospitals are also prepared to work to these standards, as collection of highquality tissue is likely to benefit their own cancer research. We also recognise that universities and NHS hospitals have a wealth of expertise (precisely what we were offering through PCPS, to P\&B companies 10 years ago) and we prefer to be working towards building longerterm relationships to mutual benefit of which tissue supply would be a significant but not exclusive part. Widespread access to small volumes of human tissue for research remains a problem for smaller biotechnology companies, as there may be little apparent incentive or opportunity to develop a collaboration.

\section{Conclusion}

Our experience over the last 10 years leads us to conclude that seizing opportunities for human tissue-based research are overdue.

The legal framework in place in the UK (Scotland has separate though complementary legislation [17]) follows on the Swedish Biobank Law [18]. Global pharmaceutical companies have to comply with these and other national laws that are likely to evolve over the next few years, hopefully learning from those already in place. At the same time, other national initiatives for example in the UK [19], USA [20] and internationally [21] are producing guidelines for collecting tissue for cancer research. These standards recognise the importance of high-quality human tissue underpinning research. We predict that in 
time, standards will harmonise and will be adopted and spread widely and subject to regular review.

Our original plan generated in the early 1990s was to boost the local public healthcare system boosted by collaboration with the $\mathrm{P} \& \mathrm{~B}$ industry. It is encouraging to see that message persist through the NHS Plan 2000 [22] to the present day when for example bids for biomedical research initiatives in the NHS [23] and from the Medical Research Council [24] were required to include some evidence of industry support.

Over time directly or indirectly, we have seen a huge range of attitudes to public/commercial collaboration in relation to human tissue; from the overwhelmingly welcoming and cooperative to the overtly obstructive.

Although most histopathologists have a heavy diagnostic workload and recruitment to academic pathology has been in decline, collecting tissue for research offers opportunity; pathologists are the gatekeepers of human tissue in most healthcare settings. Through collaboration we identify opportunity to raise departmental and hospital profile, gain exposure to a commercial environment, enhance opportunities for staff particularly biomedical scientists, identify departmental restructuring possibilities, increase flexibility, access new equipment and technologies, generate income, build a resource for academic research and all within a clinical and research governance framework. Through a post-mortem retrieval service, histopathologists can gain access to tissue that is not normally available surgically, provide tissue from multiple sites from an individual (a requirement for therapeutic antibody cross-reactivity studies) and importantly also provide tissue for transplantation $[9,25]$.

\section{References}

1 Gray N, Womack C, Jack SJ: Supplying commercial biomedical companies from a human tissue bank in an NHS hospital - a view from personal experience. J Clin Pathol 1999;52:254-256.

2 Womack C, Gray NM: Human research tissue banks in the UK National Health Service: law, ethics, controls and constraints. $\mathrm{Br}$ J Biomed Sci 2000;55:250-253.

$\checkmark 3$ Womack C: Ethical issues relating to supply of human tissue to the commercial biomedical sector. Cell Tissue Bank 2002;3:203209.

4 Nuffield Council on Bioethics: Human Tissue: Ethical and Legal Issues. London, Nuffield Council on Bioethics, 1995.

5 Kennedy Report: The Inquiry into the Management of Care of Children Receiving Complex Heart Surgery at the Bristol Royal Infirmary, 2001. http://www.bristol-inquiry.org. uk/

6 Redfern Report: The Report of The Royal Liverpool Children's Inquiry, 2001. http:// www.rlcinquiry.org.uk/

7 Wendler D: One-time general consent for research on biological samples. BMJ 2006;332: 544-547.

$>8$ Jack AL, Womack C: Why surgical patients do not donate tissue for commercial research: review of records. BMJ 2003;327: 262. $\checkmark 9$ Womack C, Gray NM, Pearson JE, Fehily D: Cadaveric tissue supply to the commercial sector for research: collaboration between NHS pathology and NBS Tissue Services extending the options for donors. Cell Tissue Bank 2001;2:51-55.

10 Womack C, Jack AL: Family attitudes to research using samples taken at coroner's postmortem examinations: review of records. BMJ 2003;327:781-782.

11 Human Tissue Act 2004. http://www.opsi. gov.uk/acts/acts2004/20040030.htm

12 Human Tissue Authority. www.hta.gov.uk

13 NHS National Patient Safety Agency Central Office for Research Ethics Committees. Standard operating procedures for research ethics committees, 2006, pp 198-212. http:// www.corec.org.uk/applicants/help/docs/ SOPs.pdf

14 Council of Europe: Convention for the Protection of Human Rights and Dignity of the Human Being with Regard to the Application of Biology and Medicine: Convention on Human Rights and Biomedicine. Oviedo, 4.IV.1997. Article 21.

15 National Health Service and Community Care Act 1990. http://www.opsi.gov.uk/ ACTS/acts1990/Ukpga_19900019_en_ 1.htm

16 Womack C, Jack AL, Musson R, Lowe JS: Pathology liaison nurses: new roles for pathology and for nurses. Bull R Coll Pathol 2003; 124:22-25.

17 The Human Tissue (Scotland) Act 2006 (Commencement) Order 2006. http://www. opsi.gov.uk/legislation/scotland/ssi2006/ 20060251.htm
18 Swedish Act on Biobanks 2003. http://www. biobanks.se/ethics.htm

19 OnCore. http://www.oncoreuk.org/

20 National Cancer Institute. How to establish and manage a tissue bank or other specimen resource. http://cancerdiagnosis.nci.nih.gov/ specimens/establish.html

21 International Society for Biological and Environmental Repositories. Best Practices for Repositories I: Collection, Storage, and Retrieval of Human Biological Material for Research Cell Preservation Technology 2005;3: 5-48.

22 National Health Service: The NHS Plan: a plan for investment, a plan for reform. 2000. http://www.dh.gov.uk/PublicationsAnd Statistics/Publications/PublicationsPolicy AndGuidance/Publications PolicyAnd GuidanceArticle/fs/en?CONTENT_ID= 4002960\&chk=07GL5R

23 National Health Service. National Institute for Health Research. Biomedical Research Centres. http://www.nihr.ac.uk/programmes_ biomedical_research_centres.aspx

24 Medical Research Council. MRC biomarkers: call for proposals. http://www.qub.ac.uk/ rrs/webpages/fund/Download/Biomarkers $\% 20$ call\%20for\%20proposals.pdf

25 Leeds Teaching Hospitals Trust: Leeds Tissue Bank. Making a GIFT for Research. http://www.gift.leeds.ac.uk/index.html 